\title{
SETTLEMENT, THE INSURERS' DILEMMA
}

\author{
DARRELL T. BRAIOWOOD*
}

Canadian insurers in the automobile insurance field face serious problems as to what rights and obligations they may have to settle claims against the insured, prior to trial. The situation in this regard is much different in the United States, where a greater body of jurisprudence has developed.

Most automobile insurance policies in force in Canada contain an agreement under which the insurer agrees substantially

“. . to serve any person insured by ... such negotiations with the claimant, or by such settlement of any resulting claims as may be deemed expedient by the insurer"1

Correspondingly, the insured agrees not to engage in settlement on his own behalf." In the United States such clauses have been taken to impose in many cases an obligation on the insurer to settle, subject to certain rules set out in the cases. There is considerable doubt as to what the situation is in Canada.

In 1950, Mr. Douglas Brown, Q.C., wrote an extensive article on some aspects of this problem, ${ }^{3}$ discussing at length the standards of care which must be observed by an insurer in deciding whether or not to settle, and what the terms of settlement should be. He pointed out that the only real authority is to be found in the United States decisions, where there have been two basic rules developed, one being the "bad faith rule" and the other the "negligence rule".

Robert Keeton notes' that an insurer's duty to settle is usually said to be a duty sounding in tort, rather than in contract. He deals with many cases on the subject, citing for the proposition that only the good faith rule is required, among others, Georgia Casualty Co. v. Mann, City of Wakefield v. Globe Indemnity Co." and Radio Taxi Service Inc. v. Lincoln Mutual Ins. Co.' Some of the cases he cites for the proposition that the insurer must observe both good faith towards the insured and ordinary care, are Douglas v. U.S. Fidelity \& Guaranty Co.," Dumas v. Hartford Accident \& Indemnity Co., ${ }^{\circ}$ and G. A. Stowers Furniture Co. v. Am. Indemnity Co. ${ }^{10}$

Yet it would seem to the writer that whichever rule the various American courts may follow, nevertheless the application seems to be very similar. As one writer says, "Are negligence and bad faith tending to approach each other like rails as they stretch away in the distance?"11

- M.A., Gradunte of Oscoode Hall, member of the BrJtlsh Columbla Bar, Natlonal Chairman of the Insurance Law Section of the Canadlan Bar Assocjation.

1 (Cf. Alberta Insurance Act, R.S.A. 1955 c. 159 s. 295 (1) (a)-Dd.]

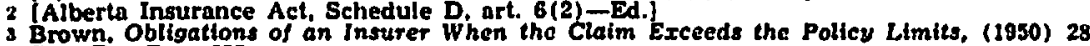

Can. Bar Rev. 635.

Keeton, Ancillary Rights of the Insured Against His Llabllity Insurer, [1861] Ins. Counsel J. 395.

(1932) 242 Ky. 447, 46 S.W. 2d 777.

(1929) 225 N.W. 643

$T$ (1960) 157 All. $2 d$ d 319

(1924) 127 Atl. 708

(1947) 56. Atl. 2d 57.

(1829) is S.W. 2d 544

11 Lowther. Loss Bocatise the Instrer Doos Not Setle, [1049] Ins. Counsol J. 92. 
Mr. Brown refers to the following comment by the court in Hilker v. Western Automobile Ins. Co.: ${ }^{12}$

"Terms which are not strictly convertible or synonymous have been used by different Courts to indicate the same thing. Negligence has been used by some Courts to mean the same thing that the Courts have designated as bad faith ..."

The question squarely confronts an insurer who is faced with the possibility of settlement rather than going on and defending an action involving a claim. What must he do, what steps must he take, and whose interests must he serve? Can the insurer become liable to the insured if he fails to settle and subsequently the insured is faced with a judgment in excess of the policy limits?

It is surprising to note that there are a great many cases arising regularly in the United States on the decision of an insurer as to whether to settle or litigate. The cases in one digest for 1963 illustrate the frequency of such questions arising.

In Kingman v. National Indemnity $\mathrm{Co}^{13}$ the Court of Appeal of Wisconsin held the insurer bound to exercise good faith when choosing to litigate a claim rather than accepting an offer of settlement within policy limits. Palmer v. Financial Indemnity Co. ${ }^{14}$ also saw the California Court of Appeal decide that the insurer must exercise good faith in considering an offer of compromise within the policy limits, while in Ferris v. Employers Mutual Casualty Co. ${ }^{21}$ an Iowa court held that the insured could not expect the automobile liability insurer to make settlement beyond what it honestly thought the situation required. Stewart v. Wood ${ }^{10}$ was a decision of the Lousiana Appeal Court holding that the insurer's refusal to compromise claims was not so arbitrary as to warrant an increase in awards beyond the coverage. In George v. Nationwide Ins. Co. ${ }^{1:}$ the Pennsylvania Court of Common Pleas held that an insurer may be liable for the whole judgment obtained by a third party against the insured (regardless of any limitation in the policy) if the insurer's handling of the claim, including a failure to accept a preferred settlement, was such as to indicate bad faith on the part of the insurer in discharging its contractual obligation. Over the years such cases may be multiplied many times showing how active this area of litigation is in the United States.

Again in the United States once the good faith rule or the negligence rule (or a combination of them) is considered, a second problem arises as to how much consideration the insurer must give to its own interests as opposed to the interests of the insured. In general, it would appear that the problem has been resolved by requiring the insurer to give as much weight to the insured's interest as it gives to its own. ${ }^{18}$ This can only cause the insurer more headaches as to what steps should he take in respect to the adjustment and possible settlement of the claim made.

The American writers feel that the insurance policy is a contract to

12 (1931) 235 N.W. 413.

13 (1963) 317 Fed. $2 d 850$.

14 (1963) 30 Cal. R. 204.

15 (1963) 122 N.W. $2 d 263$.

10 (1963) 153 So. $2 d 497$.

17 27 D. \& C. $2 d 773$.

18 This matter is discussed by Keeton, Liability Insurance and Responsibility for Settlement, (1954) 67 Harv. L. Rev. 1136. 
which the usual rules of contract law apply, and from which flows certain rights and liabilities. ${ }^{19}$ Thus in Dumas v. Hartford ${ }^{20}$ the court said:

"The standard of care is at least what a reasonable man would exercise in the management of his own affairs. Since a liability insurer has absolute control over any negotiations for a settlement or compromise of claims against the insured, some Courts have adopted the rule that insurer will be held to that degree of care and diligence which a man of ordinary care and prudence should exercise in the management of his own business."

Treating this as a matter of contract, many American writers take the position that the insured elects his limits by what he buys under his policy, and this governs the protection he receives.

The cases cast a duty on the insurer to protect the insured. In the space available one can only indicate the type of problems that arise without going into detail as to how they have been resolved in all the various jurisdictions.

The difficulties are compounded where there are multiple claimants. This brings up the problem of what has been termed "preferential settlement." Should an insurer be liable in excess of his policy limits if, acting in good faith and without negligence, he makes settlements with some claimants and then subseqnently finds his insured faced with other claims, the total of which would in the aggregate exceed the policy limits?"1

The leading American case in this field is Bartlett v. Travelers' Ins. Co. ${ }^{22}$ where the court indicated that the avoidance of litigation by compromise was to be favoured, and rejected an argument that a liability insurer could settle claims only at the risk of being liable above its policy limits. Such a rule would necessarily require the reduction of all claims to judgment, with a consequent tying up of the Courts.

In Bennett v. Conrady ${ }^{23}$ a Kansas court held that an automobile liability insurer which had settled in good faith with two claimants before three other claimants obtained judgments against the insured was liable to the latter only for the amount by which its maximum liability under the policy exceeded the amounts of the settlements made, such amounts to be paid to the three claimants pro rata to the amounts of their judgment. in Alford v. Textile Ins. Co. ${ }^{24}$ it was held that the insurer was liable to a plaintiff only for the amount that its total liability exceeded the settlements already made, since an insurer could settle part of multiple claims even though the settlements resulted in a preference by exhausting the fund to which another party whose claim had not yet been settled might otherwise look. ${ }^{25}$

The matter is further considered in an article entitled Multiple Claims Under the Automobile Liability Policy by C. L. Fisher, ${ }^{20}$ who indicates that the Bartlett case and two others ${ }^{27}$ are the only authorities allowing an insurer to settle claims not founded on judgments.

10 For a discusglon on this subject, see Morrison, Liablity of Inourar for Excess JudgmentNegligence or Bad Fath? [1952] Ins. Counsel J. 12.

20 Supra, n. 9.

21 See Keeton, loc. cit supre, and note in 70 Am. L.R. Ann.(2d) 423.

22 (19s3) 117 Conn. 147, 167 Atl. 180.

28 (1957) 305 Pac. $2 d 823$.

24 (1958) 103 S.E. 2d 8, 70 A.L.R. 2d 408.

20 See, however, Frank v. Hartford Accident \& Indemnity Co., (1930) 239 N.YS. 397. aff'd 231 App. Div. 707, 245 N.Y.S. 777; and Bruyette v. Sandint, (1935) 197 N.F. 29.

20 [1952] Ins. Counsel J. 419, 421.

27 Turk v. Goldborg, (1920) 109 Atl. 732; Bruyetto v. Sendint, oupra, n. 25, 
In New York, a number of decisions restrict a claimant to a pro rata. share and purport to prevent an insurer from exercising his right to settle otherwise. ${ }^{23}$

Generally the courts have encouraged settlements, ${ }^{20}$ which prevent unnecessary litigation and the congestion of court lists and also eliminate many of the problems in actions. However, no writers indicate that the present situation is perfectly clear and none would allow settlement to go ahead regardless of any other considerations. Every decision should be carefully examined to see what specific statutory enactments are involved.

There appears to be very little Canadian authority in this field, but recently the British Columbia Court of Appeal handed down a decision in the case of Bartkow v. Merit Ins. Co. ${ }^{30}$ The facts were as follows: An owner insured under a standard automobile policy with a $\$ 20,000.00$ limit, injured Mr. and Mrs. Reinhardt, Schmidt, Bartkow, and Walker. The first three persons commenced an action against the insured which the insurer settled before trial for $\$ 15,000.00$. Bartkow and Walker subsequently commenced action and recovered judgment against the insured for about $\$ 13,000.00$. They commenced a class action against the insurer under the British Columbia Insurance $\mathrm{Act}^{21}$ to recover the said sum. At trial the insurer successfully argued that there was only $\$ 5,000.00$ left. $^{32}$

On appeal Sheppard J.A., dissenting, said that section 242 (1) merely gives an additional remedy for the recovery of those moneys which under the policy the insured could recover for his indemnity. He would have held the payment of $\$ 15,000.00$ was in good faith and in performance of the insurer's obligation to indemnify the insured.

Norris, J.A., with whom DesBrisay, C.J.B.C., concurred without written reasons, disagreed. After lengthy examination of the history of the legislation he said: ${ }^{32}$

"The effort of the legislature has been, with reference to the operation of motor vehicles, to provide through the medium of the Insurance Act and the Motor Vehicle Act, a code covering what is referred to in the Motor Vehicle Act as safety responsibility, that is to say, a provision for the safeguarding of automobile drivers, their passengers and other persons using the highways, and provision for compensation through the medium of third party insurance for persons suffering damage as a result of motor vehicle accidents whether said persons are insured or not."

He held the statute to be a remedial one providing for safety responsibility in the public interest and indicated that the statute provided "broad protection for the public." He distinguished American cases such as Bartlett ${ }^{34}$ and held that Bartkow and Walker were entitled

28 Fisher, loc. ctt. supra, at 423.

20 See Ideal Investments Lid. v. Westminster Fire, (1962) 36 W.W.R. 476; Bcnnett v. Conrady, supra, n. 23, Bartlett v. Travelers Ins. Co., supra, n. 22.

30 (1962) 39 W.W.R. 96.

31 R.S.B.C. 1960 c. $197,8.242(1)$;

"(i) Any person having a clalm asalngt an insured, for which Indemnlty is provided by a motor vehlcle jablitity polley 13 , notwithstanding that such person is not a party to the contract, entlted, upon recovering a Judgment therefor agalnst the Insured to have the insurance money payable under the policy applled in or towards satisfactlon of his Judement and of any other Judements or clalms against the Insured covered by of his Judsment and of any olh judgments or cJains against the lnsured covered by judsments or claims, maintain an actlon against the Insurer to have the insurance money so applled."

[Cf. R.S.A. 1955, c. 159, s. 302(1), am. 1958, c. 31, 8. 6-1d.]

32 (1962) 36 W.W.R. 292.

a3 (1968) 39 W.W.R. 98, 104.

34 Supra, n. 22. 
to recover the full amount of their judgments. He went on to say: ${ }^{3 s}$

"With reference to the statement by the learned trial Judge that the respondent insurer was being required to pay more than it was required to pay by way of indemnity under the policy, it might be pointed out that if this be the case, it is the result of the voluntary action on the part of the insurer taken at his own risk, in paying the Reinhardts and Schmidt and in ignoring the statutory provisions of Section 242 in favour of other injured third parties."

Thus it would seem that the insurer's rights of settlement are severely curtailed. The British Columbia court has departed, it is suggested, from the fundamental approach of the American courts that the matter is governed by the law of contract by introducing considerations of public policy and remedial statutes to enforce that public policy.

There seems to be no doubt that claimants should have protection against preferential settlements. Nevertheless, full litigation of all claims may not be the best answer to the difficulty. This would add greatly to the number of cases before the courts and would increase the costs tremendously. Eventually this cost would be borne by the insured in the form of increased premiums. In areas where insurance is compulsory or virtually compulsory, there would soon be a public reaction.

The problem is one that may well trouble insurers and insurance counsel. In making settlement how, for example, can the insurer be satisfied that he knows of all the claims? To put the matter at its worst, suppose that in a jurisdiction allowing infants to commence action within one year after they become twenty-one, an infant is injured in an accident. Surely settlement then could be made only with great risk, in view of the potential claims which might arise years later.

The problem here is important enough to merit legislative study and action, and in at least one jurisdiction some statutory steps appear to have been taken. ${ }^{36}$ In any event, the law as it appears to be in courts which follow the judgment in the Bartkow case ${ }^{37}$ certainly causes the insurer to take a great risk in settlement unless the circumstances are absolutely clear. Even if the insurer follows all the tests and rules laid down for settlements, he may still run into grave difficulty, and perhaps become liable well beyond the amount for which he contracted.

35 (1962) 39 W.W.R. 96, 111.

36 In Alfond v. Textile Ins. Co., supra, n. 24, the court noted a statule passed after the accident, whereby insurers were authorized to Insert in pollcles a clause allowing them to settle claims in good faith, with a resulting deduction from the total amount of contractual liability.

37 Supre, n. 30 . 